ORIGINAL PAPER

\title{
HUMAN PAPILLOMA VIRUS INFECTION IN BASAL \\ CELL CARCINOMA OF THE SKIN: A SYSTEMATIC REVIEW \\ AND META-ANALYSIS STUDY
}

Mazaher Ramezani ${ }^{1}$, Masoud Sadeghi ${ }^{2,3}$

${ }^{1}$ Molecular Pathology Research Center, Emam Reza Hospital, Kermanshah University of Medical Sciences, Kermanshah, Iran

${ }^{2}$ Medical Biology Research Center, Kermanshah University of Medical Sciences, Kermanshah, Iran

${ }^{3}$ Students Research Committee, Kermanshah University of Medical Sciences, Kermanshah, Iran

\begin{abstract}
Human papillomaviruses (HPVs) are a large and ubiquitous group of viruses that some of them have been suggested as a co-factor in the development of non-melanoma skin cancers. The aim of this meta-analysis study was to evaluate HPVs' prevalence in basal cell carcinoma (BCC) of the skin and the risk of them in the BCC patients compared with the healthy controls. Five databases were searched from January 1980 to February 2017. A random-effects meta-analysis was done with the event rate (ER) for the prevalence of HPVs and odds ratio (OR) for estimation of the incidence of HPVs. Out of 1087 studies, 45 studies were included in the review. The pooled analysis demonstrated that the incidence of $\gamma$-HPV was effective in the BCC patients compared with the healthy controls [OR $=1.97$; $95 \% \mathrm{CI}: 1.52-2.55$; $\mathrm{p}<$ $0.00001]$, but not for $\alpha-\mathrm{HPV}, \beta-\mathrm{HPV}$ and epidermodysplasia verruciformis (EV)$\mathrm{HPV}(\mathrm{p}>0.05)$. The pooled ER of incidence of $\beta 1-\mathrm{HPV}$ in the BCC patients was $33.3 \%$ and for $\beta 2-\mathrm{HPV}$ in BCC patients was $44.2 \%$. In conclusion, this meta-analysis showed that probably the risk of $\gamma$-HPV was more on BCC patients and also the rate of $\gamma$-HPV was higher than $\alpha-, \beta$ - and EV-HPVs in the BCC patients.
\end{abstract}

Key words: human papilloma virus, basal cell carcinoma, prevalence, incidence.

\section{Introduction}

Human papillomaviruses (HPVs) are a large and ubiquitous group of viruses that can accompany benign, pre-malignant and malignant proliferations of the epithelium [1]. About $5 \%$ of all cancers in the world can be related to HPVs [2, 3]. More than 200 HPV types have been described and divided into five major genera: $\alpha$-, $\beta$-, $\gamma$-, $\mu$ - and $\nu$-papillomavirus [4]. HPVs can be divided into cutaneous types commonly found in common warts, mucosal types detected in genital condylomas and anogenital cancers and epidermodysplasia verruciformis (EV) types
$[5,6] . \mathrm{EV}$ is a rare genodermatosis associated with infections with specific HPVs belonging to the $\beta$ genus of HPV [7]. Some of the cutaneous HPVs of the genus $\beta$ have been suggested as a co-factor in the development of non-melanoma skin cancer (NMSC) $[1,8]$. NMSCs are squamous cell carcinomas (SCC) and basal cell carcinomas (BCC) that BCC is the most common skin malignancy and represents approximately $75 \%$ of all skin cancers, mostly in the sun-exposed areas [9, 10]. HPV is increasingly considered as an important human carcinogen, but its role in the etiology and pathogenesis of BCC in immunocompetent individuals is unclear [11]. A sig- 
nificant problem for investigations of an association between cutaneous HPV and non-melanoma skin cancer is that cutaneous HPV is part of the normal flora of human skin [12].

The aim of this meta-analysis study was to determine HPVs' prevalence in the BCC patients and the risk of them in the $\mathrm{BCC}$ patients compared with the health controls.

\section{Material and methods}

\section{Search strategies}

A comprehensive search was done with search terms included with "basal cell carcinoma OR BCC" and "HPV or human papillomavirus" in databases of PubMed/Medline, Web of Science, Science Direct, Scopus, and Cochrane Library from January 1980 to February 2017.

\section{Study selection}

Two authors revised selection of the studies. The first author (M.S) searched the studies and then the second author (M.R) screened them. Both authors assessed the studies based on criteria for selecting the studies included in this study. The studies included the following inclusion criteria: a) case-control, cohort or cross-sectional studies; b) human studies; c) reporting of the prevalence of HPVs in serum and/or tissue of the patients with BCC of the skin; d) reporting of the incidence of HPVs in serum or tissue of the BCC patients (BCC group or BCC patients) compared with serum or tissue of the controls (control group).

\section{Data extraction}

We extracted the name of author, the year of publication, country, the number of BCC patients, the number of patients in the control group (if), the number of HPV positivity in the BCC patients, the number of HPV positivity in the health controls (if), the type of HPV, the method of HPV detection and immune status of each study included in the review.

\section{Statistical analysis}

A random-effects meta-analysis was used by Comprehensive Meta-Analysis software version 2.0 (CMA 2.0) using the event rate (ER) and Review Manager 5.3 (RevMan 5.3, The Cochrane Collaboration, Oxford, United Kingdom) using odds ratio (OR) and 95\% confidence intervals (CIs) for estimation of the incidence of HPV. Heterogeneity between estimates was assessed by the $\mathrm{Q}$ and $\mathrm{I}^{2}$ statistic that for the $\mathrm{Q}$ statistic, heterogeneity was considered for $\mathrm{p}<0.1$. Two-sided p-value $<0.05$ was considered to be statistically significant in this meta-analysis study.

\section{Results}

\section{Selection of studies}

Out of 1087 studies, 92 studies evaluated for eligibility (Fig. 1). Forty-seven studies were excluded because they were case-report, review studies, didn't report the prevalence of HPVs in BCC patients or report just one BCC patient. Therefore, 45 studies were included in the systematic review.

\section{Characteristics of studies}

Out of 45 studies reported during 1991 to 2017; two studies were reported in Australia [12, 13], one Romania [14], ten USA [15, 16, 17, 18, 19, 20, 21, 22, 23, 24], one Argentina [1], four Netherlands [25, 26, 27, 28], two Spain [8, 11], one Brazil [29], one China [30], one UK [31], one Croatia [2], four Iran [9, 32, 33, 34], one North Africa/France [35], one Germany/USA [36], two Greece [37, 38], one Sweden/Austria [39], two Germany [40, 41], five Italy [5, 42, 43, 44, 45], one Russia [46], one Germany/Poland [47], one Norway/Sweden [48] and two Sweden [49, 50] (Table I). Fifteen studies were case-control and 30 studies were cross-sectional studies. Twenty-four studies did polymerase chain reaction (PCR) $[1,2,12,14,19,20,21,25,28,29,31$, 32, 35, 36, 37, 39, 40, 41, 42, 43, 44, 46, 47, 49, 50], 2 in situ hybridization (ISH) [15, 18], 3 serology [16, 48, 24], 7 nested PCR [5, 8, 11, 26, 27, 34, 43], one loop-mediated isothermal amplification assay (LAMP)/PCR [30], 4 multiplex serology [17, 22, 38, 45], 2 immunohistochemistry (IHC) [9, 33], one

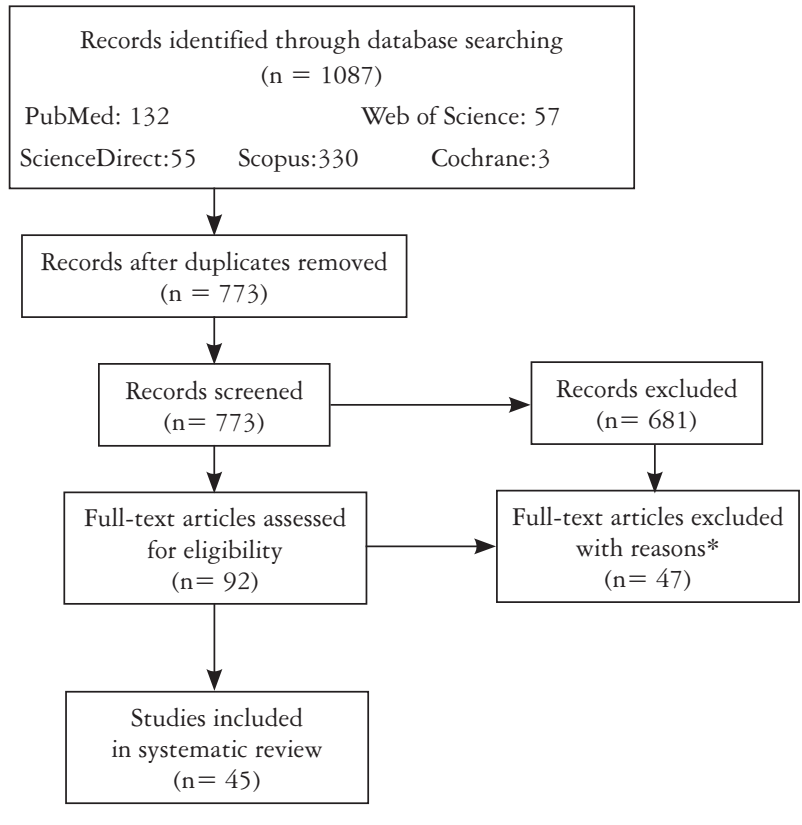

*5 were report studies; 2 were review studies; 1 study reported just one BCC patient, 39 studies not reported the prevalance of HPVs

Fig. 1. The flowchart of study 
Table I. The characteristics of studies included in meta-analysis $(n=45)$

\begin{tabular}{|c|c|c|c|c|c|c|}
\hline STUDY (YEAR) & Country & $\begin{array}{c}\text { STUDY } \\
\text { TYPE }\end{array}$ & $\mathrm{BCC}$ & Controls & $\begin{array}{c}\text { METHOD OF HPV } \\
\text { DETECTION }\end{array}$ & $\begin{array}{l}\text { IMMUNE } \\
\text { STATUS }\end{array}$ \\
\hline Correa et al. 2017 [1] & Argentina & CS & 96 & - & PCR & IC/IS \\
\hline Drvar et al. 2014 [2] & Croatia & CS & 13 & - & PCR & $\mathrm{N} / \mathrm{S}$ \\
\hline Zakrzewska et al. 2012 [5] & Italy & CS & 100 & - & Nested PCR & IC \\
\hline Bernat-García et al. 2014 [8] & Spain & CS & 26 & - & Nested PCR & IC/IS \\
\hline Mokhtari et al. 2009 [9] & Iran & CS & 80 & - & $\mathrm{IHC}$ & $\mathrm{N} / \mathrm{S}$ \\
\hline Escutia et al. 2011 [11] & Spain & $\mathrm{CC}$ & 70 & 72 & Nested PCR & IC \\
\hline Forslund et al. 2003 [12] & Australia & CS & 25 & - & PCR & IC/IS \\
\hline Trenfield et al. 1993 [13] & Australia & CS & 11 & - & Southern blot & IS \\
\hline Rotaru et al. 2014 [14] & Romania & $\mathrm{CC}$ & 20 & 40 & PCR & IC \\
\hline Elwood et al. 2014 [15] & USA & Cohort & 13 & - & ISH & $\mathrm{N} / \mathrm{S}$ \\
\hline Iannacone et al. 2013 [16] & USA & $\mathrm{CC}$ & 224 & 300 & Serology & $\mathrm{N} / \mathrm{S}$ \\
\hline Karagas et al. 2006 [17] & USA & $\mathrm{CC}$ & 525 & 461 & Multiplex Serology & $\mathrm{N} / \mathrm{S}$ \\
\hline Gibson et al. 2001 [18] & USA & CS & 51 & - & ISH & $\mathrm{N} / \mathrm{S}$ \\
\hline Pierceall et al. 1991 [19] & USA & CS & 16 & - & PCR & $\mathrm{N} / \mathrm{S}$ \\
\hline Karagas et al. 1997 [20] & USA & $\mathrm{CS}$ & 25 & - & PCR & $\mathrm{N} / \mathrm{S}$ \\
\hline Patel et al. 2008 [21] & USA & CS & 98 & - & PCR & IC \\
\hline Karagas et al. 2010 [22] & USA & $\mathrm{CC}$ & 898 & 805 & Multiplex Serology & $\mathrm{N} / \mathrm{S}$ \\
\hline Rollison et al. 2008 [23] & USA & CS & 15 & - & $\begin{array}{l}\text { Multiplex Serology/ } \\
\text { PCR }\end{array}$ & $\mathrm{N} / \mathrm{S}$ \\
\hline Iannacone et al. 2012 [24] & USA & CS & 204 & 297 & Serology & $\mathrm{N} / \mathrm{S}$ \\
\hline Tieben et al. 1994 [25] & Netherlands & CS & 4 & - & PCR & IS \\
\hline de Jong-Tieben et al. 1995 [26] & Netherlands & $\mathrm{CC}$ & 8 & 23 & Nested PCR & IC/IS \\
\hline Berkhout et al. 2000 [27] & Netherlands & CS & 14 & - & Nested PCR & IS \\
\hline Feltkamp et al. 2003 [28] & Netherlands & $\mathrm{CC}$ & 432 & 333 & PCR & $\mathrm{N} / \mathrm{S}$ \\
\hline Berberta et al. 2004 [29] & Brazil & $\mathrm{CC}$ & 23 & 9 & PCR & $\mathrm{N} / \mathrm{S}$ \\
\hline Yang et al. 2016 [30] & China & CS & 50 & - & LAMP/ PCR & $\mathrm{N} / \mathrm{S}$ \\
\hline Harwood et al. 2000 [31] & UK & CS & 54 & - & PCR & IC/IS \\
\hline Nahidi et al. 2015 [32] & Iran & $\mathrm{CC}$ & 42 & 42 & PCR & $\mathrm{N} / \mathrm{S}$ \\
\hline Ramezani et al. 2016 [33] & Iran & $\mathrm{CC}$ & 53 & 44 & $\mathrm{IHC}$ & $\mathrm{N} / \mathrm{S}$ \\
\hline $\begin{array}{l}\text { Shahmahmoudi et al. } 2007 \\
\text { [34] }\end{array}$ & Iran & Cohort & 99 & - & Nested PCR & $\mathrm{N} / \mathrm{S}$ \\
\hline Luron et al. 2007 [35] & $\begin{array}{l}\text { North Africa/ } \\
\text { France }\end{array}$ & CC & 27 & 9 & PCR & IS \\
\hline Iftner et al. 2003 [36] & Germany/USA & $\mathrm{CC}$ & 18 & 106 & PCR & IC \\
\hline Zaravinos et al. 2010 [37] & Greece & $\mathrm{CC}$ & 15 & 53 & PCR & IC \\
\hline Biliris et al. 2000 [38] & Greece & CS & 72 & - & Multiplex PCR & IC \\
\hline Forslund et al. 2004 [39] & Sweden/Austria & CS & 109 & - & PCR & IC \\
\hline Reuschenbach et al. 2011 [40] & Germany & Cohort & 53 & - & PCR & IC/IS \\
\hline Stockfleth et al. 2004 [41] & Germany & CS & 64 & - & PCR & IS \\
\hline Posteraro et al. 1996 [42] & Italy & CS & 25 & - & PCR & IC \\
\hline Paolini et al. 2011 [43] & Italy & $\mathrm{CC}$ & 37 & 37 & Nested PCR & $\mathrm{N} / \mathrm{S}$ \\
\hline Borgogna et al. 2014 [44] & Italy & Cohort & 31 & - & PCR & IS \\
\hline
\end{tabular}


Table I. The characteristics of studies included in meta-analysis $(n=45)$

\begin{tabular}{|c|c|c|c|c|c|c|}
\hline STUDY (YEAR) & COUNTRY & $\begin{array}{l}\text { STUDY } \\
\text { TYPE }\end{array}$ & BCC & Controls & $\begin{array}{c}\text { MeTHOD OF HPV } \\
\text { DETECTION }\end{array}$ & $\begin{array}{l}\text { IMMUNE } \\
\text { STATUS }\end{array}$ \\
\hline Paradisi et al. 2011 [45] & Italy & Cohort & 49 & - & Multiplex Serology & $\mathrm{N} / \mathrm{S}$ \\
\hline Shamanin et al. 1996 [46] & Russia & CS & 16 & - & PCR & IC/IS \\
\hline Wieland et al. 2000 [47] & Germany/Poland & CS & 69 & - & PCR & IC \\
\hline Andersson et al. 2012 [48] & Norway/Sweden & Cohort & 1990 & - & Serology & $\mathrm{N} / \mathrm{S}$ \\
\hline Faust et al. 2013 [49] & Sweden & CS & 160 & - & PCR & IC \\
\hline Andersson et al. 2008 [50] & Sweden & $\mathrm{CS}$ & 160 & - & PCR & $\mathrm{N} / \mathrm{S}$ \\
\hline
\end{tabular}

multiplex serology/PCR [23] and one southern blot [13] for detection of HPV. Also, immune status were immunocompetent/immunosuppressed (IC/IS) in 7 studies $[1,8,12,26,31,40,46]$, IC in 11 studies $[5,11,14,21,36,37,38,39,42,47,49]$, IS in 6 studies $[13,25,27,35,41,44]$ and 21 studies didn't report any status $[2,9,15,16,17,18,19,20,22,23$, $24,28,29,30,32,33,34,43,45,48,50]$. Out of 45 studies, seven studies checked HPVs on the serum $[16,17,22,38,45,48,24]$ and the rest of studies on the BCC-involved and healthy tissues.

\section{Meta-analysis}

Figure 2 shows the incidence of number of HPVs in the BCC patients and controls. Some studies reported this incidence in the BCC patients and controls (case-control studies) and other studies only reported in BCC patients (cross-sectional and cohort studies).

\section{$\alpha-\mathrm{HPV}$}

Seven studies $[1,14,16,17,24,37,43]$ reported the prevalence of $\alpha-\mathrm{HPV}$ in the BCC patients and/ or controls. Out of 1121 BCC patients, 338 (30.1\%) were HPV positivity and out of 1188 controls, 358 (30.1\%) were HPV positivity. The pooled analysis with dichotomous data demonstrated that the incidence of $\alpha-\mathrm{HPV}$ was not effective in the BCC patients compared with the healthy controls $[\mathrm{OR}=1.45 ; 95 \%$ CI: $0.90-2.33 ; \mathrm{p}=0.12]$ and $\left[\mathrm{I}^{2}=78 \% ; \mathrm{p}=0.001\right]$ (Fig. 3).

\section{$\beta-\mathrm{HPV}$}

Seven studies $[1,16,17,22,24,32,43]$ reported the prevalence of $\beta$-HPV in the BCC patients and/or controls. Out of 2379 BCC patients, 951 (40\%) were HPV positivity and out of 1942 controls, 863 (44.4\%) were HPV positivity. The pooled analysis with dichotomous data demonstrated that the incidence of $\beta$-HPV was not effective in the BCC patients compared with controls [OR $=1.10 ; 95 \% \mathrm{CI}: 0.83-1.45 ; \mathrm{p}=0.50]$ and $\left\{\mathrm{I}^{2}=64 \% ; \mathrm{p}=0.02\right\}$ (Fig. 3).

\section{$\gamma-\mathrm{HPV}$}

Four studies $[1,16,24,43]$ reported the prevalence of $\gamma$-HPV in BCC patients and/or controls. Out of 561 BCC patients, 291 (51.9\%) were HPV positivity and out of 634 controls, 310 (48.9\%) were HPV positivity. The pooled analysis with dichotomous data demonstrated that the incidence of $\gamma$-HPV was effective in the BCC patients compared with controls $[\mathrm{OR}=1.97 ; 95 \% \mathrm{CI}: 1.52-2.55 ; \mathrm{p}<0.00001]$ and $\left[\mathrm{I}^{2}=0 \% ; \mathrm{p}=0.89\right\}$ (Fig. 3).

\section{Epidermodysplasia verruciformis-HPV (EV-HPV)}

Six studies $[11,25,26,31,35,36]$ reported the prevalence of EV-HPV in the BCC patients and/or controls. Out of 181 BCC patients, 39 (21.5\%) were HPV positivity and out of 210 controls, $16(7.6 \%)$ were HPV positivity. The pooled analysis with dichotomous data demonstrated that the incidence of EV-HPV was not effective in the BCC patients compared with controls $[\mathrm{OR}=2.04 ; 95 \% \mathrm{CI}: 0.52$, 7.98; $\mathrm{p}=0.31]$ and $\left[\mathrm{I}^{2}=47 \% ; \mathrm{p}=0.13\right]$ (Fig. 3).

\section{$\alpha-H P V$ based on subgroups}

Figure 4 shows the event rate of HPV 3, HPV 18, HPV 16, HPV 31, HPV 33, HPV 6 and HPV 11 in the BCC patients. Two [45, 49], six [15, 18, 19, 38, $34,49]$, eleven $[2,15,18,19,20,28,34,38,45$, $49,50]$, two [18, 49], three [18, 38, 49], four [18, $45,49,50]$, and three studies $[18,38,49]$ reported the prevalence of HPV $3(\alpha 2)$, HPV $18(\alpha 7)$, HPV $16(\alpha 9)$, HPV $31(\alpha 9)$, HPV $33(\alpha 9)$, HPV $6(\alpha 10)$, and HPV $11(\alpha 10)$ in the BCC patients, respectively. Table II shows the pooled ER of the articles for the incidence of $\alpha$ - HPVs in the BCC patients. 

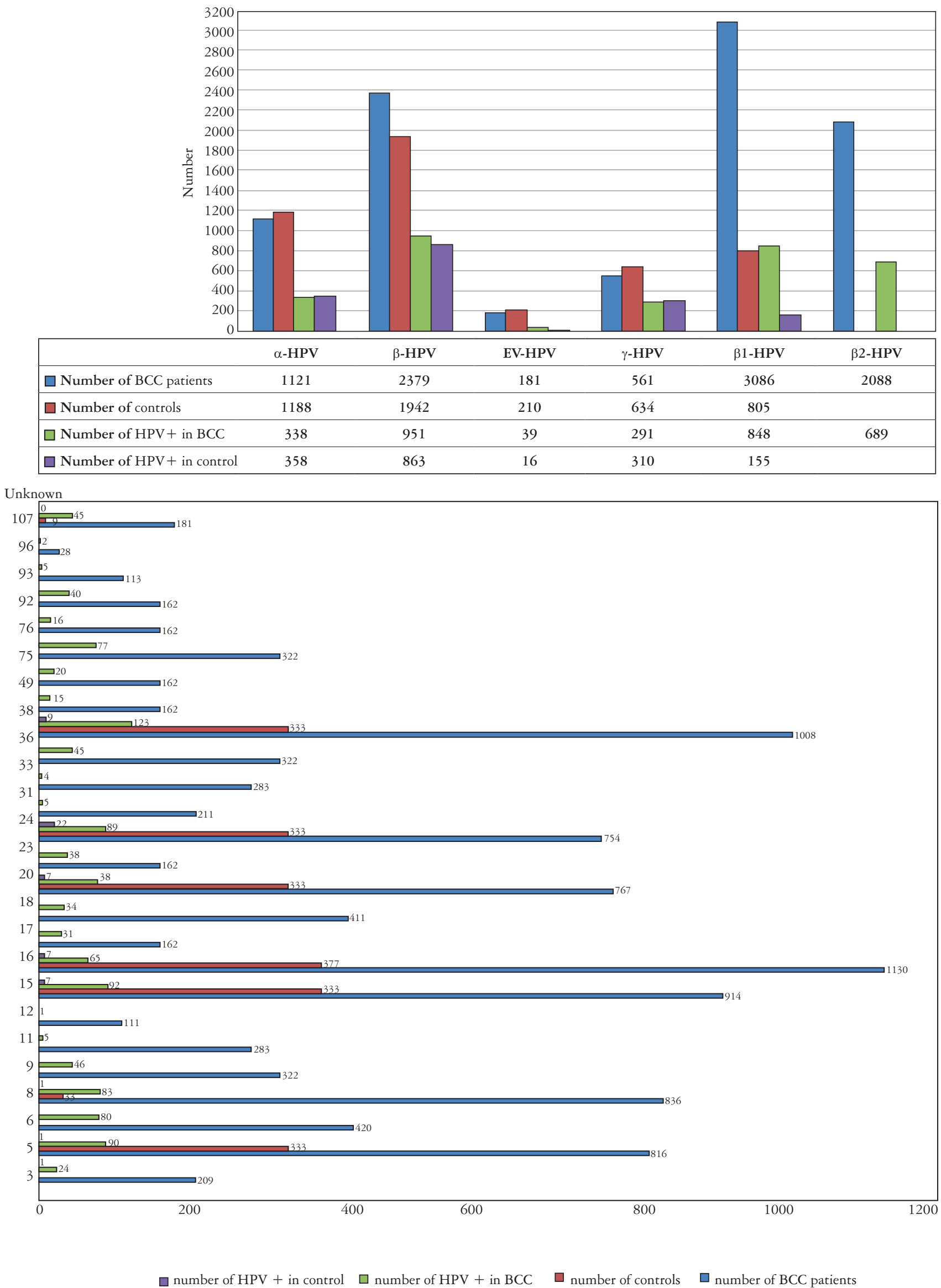

Fig. 2. The incidence of a number of HPVs in BCC patients and controls 


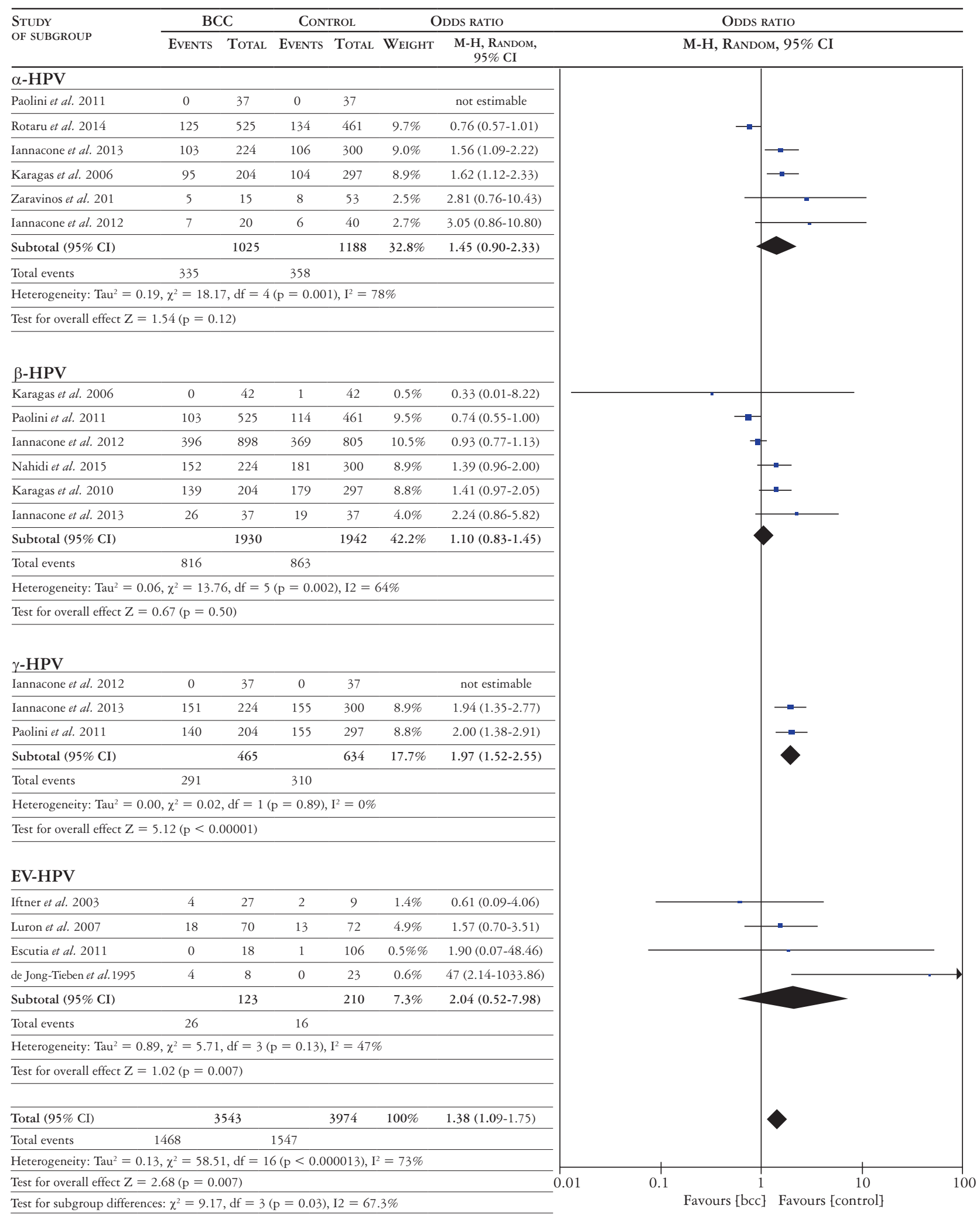

Fig. 3. The forest plot of odds ratios for the risk impact of $\alpha-\mathrm{HPV}, \beta-\mathrm{HPV}, \gamma-\mathrm{HPV}$ and EV-HPV in BCC patients compared with controls 
A

\begin{tabular}{|c|c|c|c|c|}
\hline \multirow[t]{2}{*}{ Study name } & \multirow[t]{2}{*}{ HPV type } & \multicolumn{3}{|c|}{ Statistics for each study } \\
\hline & & Event rate & Lowert limit & Upper limit \\
\hline Faust et al. 2013 & 18 & 0.013 & 0.003 & 0.049 \\
\hline Elwood et al. 2014 & 18 & 0.036 & 0.002 & 0.384 \\
\hline Gibson et al. 2001 & 18 & 0.010 & 0.001 & 0.136 \\
\hline Pierceall et al. 1991 & 18 & 0.029 & 0.002 & 0.336 \\
\hline Biliris et al. 2010 & 18 & 0.139 & 0.076 & 0.239 \\
\hline Shahmahmoudi et al. 2007 & 18 & 0.222 & 0.151 & 0.315 \\
\hline Total for subgroup & & 0.053 & 0.014 & 0.181 \\
\hline Faust et al. 2013 & 3 & 0.031 & 0.013 & 0.073 \\
\hline Paradisi et al. 2011 & 3 & 0.388 & 0.263 & 0.529 \\
\hline Total for subgroup & & 0.129 & 0.018 & 0.543 \\
\hline Overall & & 0.070 & 0.023 & 0.192 \\
\hline
\end{tabular}

Statistics for each study

\begin{tabular}{|c|c|c|c|c|}
\hline \multirow[t]{2}{*}{ Study name } & \multirow[t]{2}{*}{ HPV type } & \multicolumn{3}{|c|}{ Statistics for each study } \\
\hline & & Event rate & Lowert limit & Upper limit \\
\hline Elwood et al. 2014 & 16 & 0.036 & 0.002 & 0.384 \\
\hline Gibson et al. 2001 & 16 & 0.010 & 0.001 & 0.136 \\
\hline Pierceall et al. 1991 & 16 & 0.188 & 0.062 & 0.447 \\
\hline Karagas et al. 1997 & 16 & 0.040 & 0.006 & 0.235 \\
\hline Biliris et al. 2010 & 16 & 0.007 & 0.000 & 0.100 \\
\hline Shahmahmoudi et al. 2007 & 16 & 0.061 & 0.027 & 0.128 \\
\hline Faust et al. 2013 & 16 & 0.056 & 0.030 & 0.105 \\
\hline Paradisi et al. 2011 & 16 & 0.510 & 0.373 & 0.646 \\
\hline Andersson et al. 2008 & 16 & 0.069 & 0.038 & 0.120 \\
\hline Ramezani et al. 2016 & 16 & 0.009 & 0.001 & 0.131 \\
\hline Feltkamm et al. 2003 & 16 & 0.023 & 0.012 & 0.042 \\
\hline Total for subgroup & & 0.055 & 0.022 & 0.135 \\
\hline Gibson et al. 2001 & 31 & 0.010 & 0.001 & 0.136 \\
\hline Faust et al. 2013 & 31 & 0.031 & 0.013 & 0.073 \\
\hline Total for subgroup & & 0.021 & 0.002 & 0.181 \\
\hline Gibson et al. 2001 & 33 & 0.010 & 0.001 & 0.136 \\
\hline Biliris et al. 2010 & 33 & 0.007 & 0.000 & 0.100 \\
\hline Faust et al. 2013 & 33 & 0.025 & 0.009 & 0.065 \\
\hline Total for subgroup & & 0.014 & 0.002 & 0.096 \\
\hline Overall & & 0.033 & 0.011 & 0.097 \\
\hline
\end{tabular}

Event rate and $95 \% \mathrm{CI}$

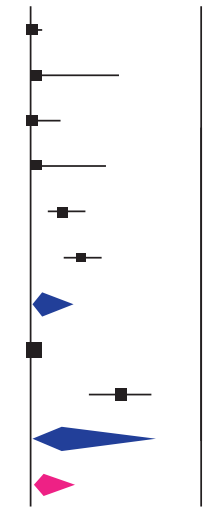

0.00

0.75

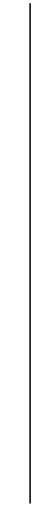

1.50

Event rate and 95\% CI

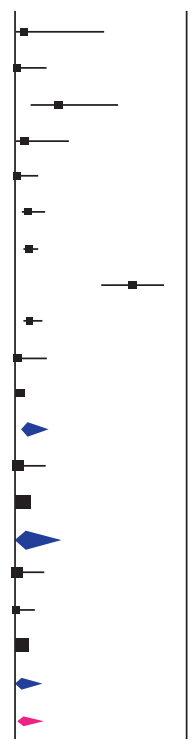

0.00

0.75

\begin{tabular}{|c|c|c|c|c|}
\hline \multirow[t]{2}{*}{ Study name } & \multirow[t]{2}{*}{ HPV type } & \multicolumn{3}{|c|}{ Statistics for each study } \\
\hline & & Event rate & Lowert limit & Upper limit \\
\hline Gibson et al. 2001 & 11 & 0.010 & 0.001 & 0.136 \\
\hline Faust et al. 2013 & 11 & 0.031 & 0.013 & 0.073 \\
\hline Biliris et al. 2010 & 11 & 0.007 & 0.000 & 0.100 \\
\hline Total for subgroup & & 0.017 & 0.003 & 0.082 \\
\hline Gibson et al. 2001 & 6 & 0.010 & 0.001 & 0.136 \\
\hline Faust et al. 2013 & 6 & 0.063 & 0.034 & 0.112 \\
\hline Paradisi et al. 2011 & 6 & 0.347 & 0.228 & 0.489 \\
\hline Andersson et al. 2008 & 6 & 0.331 & 0.263 & 0.408 \\
\hline Total for subgroup & & 0.155 & 0.055 & 0.367 \\
\hline Overall & & 0.057 & 0.006 & 0.0380 \\
\hline
\end{tabular}

Event rate and $95 \% \mathrm{CI}$

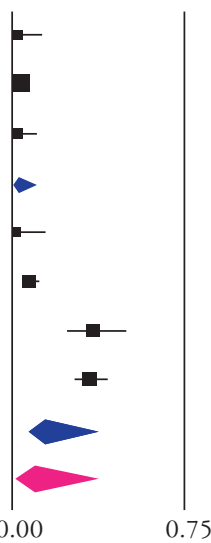

Fig. 4. The forest plot of event rate of (A) $\alpha 2$ - and $\alpha 7-\mathrm{HPVs},(\mathrm{B}) \alpha 9-\mathrm{HPV}$ and (C) $\alpha 10-\mathrm{HPV}$ in BCC patients 
Table II. The pooled ER of the articles for the incidence of $\alpha$-HPVs in BCC patients

\begin{tabular}{lccc}
\hline HPV & $\begin{array}{c}\text { NuMBER OF } \\
\text { BCC PATIENTS }\end{array}$ & ER & 95\%CI \\
\hline HPV 3 & 209 & 12.9 & $1.8-54.3$ \\
\hline HPV 18 & 411 & 5.3 & $1.4-18.1$ \\
\hline HPV 16 & 1130 & 5.5 & $2.2-13.5$ \\
\hline HPV 31 & 211 & 2.1 & $0.02-18.1$ \\
\hline HPV 33 & 283 & 1.4 & $0.02-9.6$ \\
\hline HPV 6 & 420 & 15.5 & $5.5-36.7$ \\
\hline HPV 11 & 283 & 1.7 & $0.03-8.2$ \\
\hline
\end{tabular}

\section{$\beta$-HPV based on subgroups}

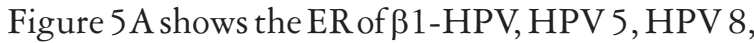
HPV 12, HPV 20, HPV 24, HPV 36 and HPV 93 in the BCC patients and Fig. 5B shows the ER of $\beta 2-$ HPV, HPV 9, HPV 15, HPV 17, HPV 23, HPV 38, HPV 75 and HPV 107 in the BCC patients. Also, Fig. 6 shows the ER of HPV 49, HPV 76, HPV 92, HPV 96 and HPV (unlisted) in the BCC patients. Three [21, 23, 45], four [21, 23, 45, 49], three [21, 23, 45], two [21, 23], and six studies [8, 9, 13, 29, $42,46]$ reported the prevalence of $\mathrm{HPV} 49(\beta 3)$, HPV 76 ( $\beta 3)$, HPV 92 ( $\beta 4)$, HPV 96 ( $\beta 5)$, and HPV (unlisted type) in the BCC patients. Four [5, 21, 22, 48], five $[23,28,45,49,50]$, seven $[2,21,23,28$, $45,47,50]$, two [2, 21], six [2, 21, 23, 28, 45, 50], five $[21,23,28,45,50]$, four $[21,23,45,50]$ and three studies $[21,23,45]$ reported the prevalence of $\beta 1$-HPV, HPV 5 ( $\beta 1)$, HPV 8 ( $\beta 1)$, HPV $12(\beta 1)$, HPV 20 ( $\beta 1)$, HPV 24 ( $\beta 1)$, HPV 36 ( $\beta 1)$, and HPV $93(\beta 1)$ in the BCC patients, respectively. In addition to, two $[21,48]$, four $[21,23,45,50]$, six [21, 23, $28,45,49,50]$, three $[21,23,45]$, three $[21,23$, $45]$, eight $[12,21,23,28,47,45,49,50]$, three [21, $23,45]$, two studies $[2,23]$ reported the prevalence of $\beta 2$-HPV, HPV 9 ( $\beta 2)$, HPV 15 ( $\beta 2)$, HPV 17 ( $\beta 2)$, HPV 23 ( $\beta 2)$, HPV 38 ( $\beta 2)$, HPV 75 ( $\beta 2)$, and HPV 107 ( $\beta 2)$ in the BCC patients, respectively. Table III shows the pooled ER of the articles for the incidence of $\beta-H P V s$ in the BCC patients.

\section{Discussion}

The BCC is an immunogenic neoplasm [51] that its pathogenesis strongly associates with environmental and genetic factors [52]. We have conducted a comprehensive systematic review of studies addressing OR and ER of HPVs in the BCC of the skin in the world. There were 45 studies in this systematic review and meta-analysis that seven studies checked HPVs on serum $[16,17,22,38,45,48,24\}$ and 38 studies on the BCC-involved tissue. Our findings
Table III. The pooled ER of the articles for the incidence of $\beta-H P V s$ in BCC patients

\begin{tabular}{|c|c|c|c|}
\hline HPV & $\begin{array}{l}\text { Number of } \\
\text { BCC PATIENTS }\end{array}$ & ER & $95 \% \mathrm{CI}$ \\
\hline$\beta 1-\mathrm{HPV}$ & 848 & 33.3 & $19.9-50$ \\
\hline HPV 5 & 816 & 13.6 & $7.2-24.1$ \\
\hline HPV 8 & 836 & 12.5 & $7.1-29$ \\
\hline HPV 12 & 111 & 1.6 & $0.02-10$ \\
\hline HPV 20 & 767 & 12.5 & $6.8-21.8$ \\
\hline HPV 24 & 754 & 13.4 & $7.2-23.5$ \\
\hline HPV 36 & 322 & 15 & $7.3-28.3$ \\
\hline HPV 93 & 162 & 23.8 & $10.8-44.8$ \\
\hline$\beta 2-\mathrm{HPV}$ & 689 & 44.2 & $20.7-70.5$ \\
\hline HPV 9 & 322 & 20.3 & $9.7-37.8$ \\
\hline HPV 15 & 914 & 13.1 & $7-23$ \\
\hline HPV 17 & 162 & 18.9 & $7.7-39.3$ \\
\hline HPV 23 & 162 & 21.9 & $8.9-44.5$ \\
\hline HPV 38 & 1008 & 14.9 & $8.8-24.1$ \\
\hline HPV 75 & 162 & 15.1 & $5.4-35.5$ \\
\hline HPV 107 & 107 & 7.2 & $1.3-31.9$ \\
\hline HPV 49 & 162 & 17.9 & $9-32.7$ \\
\hline HPV 76 & 322 & 23.4 & $15.4-33.8$ \\
\hline HPV 92 & 162 & 3.5 & $0.04-23.5$ \\
\hline HPV 96 & 113 & 6.9 & $1-35.7$ \\
\hline $\begin{array}{l}\text { HPV } \\
\text { (unlisted } \\
\text { type) }\end{array}$ & 181 & 26.4 & $9.8-54.4$ \\
\hline
\end{tabular}

showed a significant risk of $\gamma$-HPV in the BCC patients compared with the healthy controls. Among $\alpha$-HPVs reported $(3,6,11,16,18,31$ and 33$)$ in the BCC patients of skin, the highest of ER was HPV 6 $(15.5 \%)$ and lowest was HPV $33(1.4 \%)$. With regard to ER of $\beta 1-\mathrm{HPV}$ in the BCC patients $(33.3 \%)$ and among subgroups of $\beta 1$-HPV reported $(5,8,12$, 20, 24, 36 and 93), HPV 93 (23.8\%) and HPV 12 $(1.6 \%)$ had the highest and lowest of ER of $\beta 1-H P V$, respectively. With regard to ER of $\beta 2-\mathrm{HPV}$ in the BCC patients $(44.2 \%)$ and among subgroups of $\beta 2$ HPV reported (9, 15, 17, 23, 38, 75 and 107), HPV $23(21.9 \%)$ and HPV 107 (7.2\%) had the highest and lowest of ER of $\beta 2-\mathrm{HPV}$, respectively.

Correa et al. [1] demonstrated that $\beta$-HPVs were the most frequently found in BCCs compared with $\alpha$ - and $\gamma$-HPVs. Andersson et al. [48] reported that out of $\beta 2$-HPVs, HPV9 was significantly associated with BCC. Antibodies against any HPV 5, 8, 9, 15, $20,24,36$ and 38 showed that $48.8 \%$ BCC patients 
were positive while this was $53.2 \%$ among controls [50]. Escutia et al. [11] concluded $\beta$-types were frequently detected in skin samples from immunocompetent patients with BCC that there were differences in the prevalence of HPV in skin biopsies of BCC tumors and normal skin. Also, one study on HPV types (mostly $\beta$-HPV) [8] presented important differences in HPV prevalence between immunocompromised and immunocompetent patients. The higher preva- lence of HPV types (mostly $\beta$-HPV) found in healthy perilesional skin proposed that HPV DNA was widely distributed in the general population and was found no correlation between the presence of HPV and skin cancer. Another study on $\beta$-HPVs [16] suggested that the combined serology and tumor DNA results showed that $\beta$-HPVs may have a role in BCC. Two studies $\{9,45]$ did not find a significant relationship between BCC and HPV and also Nahidi et al.

A

\begin{tabular}{|c|c|c|c|c|}
\hline \multirow[t]{2}{*}{ Study name } & \multirow[t]{2}{*}{ HPV type } & \multicolumn{3}{|c|}{ Statistics for each study } \\
\hline & & Event rate & Lowert limit & Upper limi \\
\hline Patel et al. 2008 & 12 & 0.010 & 0.001 & 0.069 \\
\hline Drvar et al. 2014 & 12 & 0.036 & 0.002 & 0.384 \\
\hline Total for subgroup & & 0.016 & 0.002 & 0.100 \\
\hline Patel et al. 2008 & 20 & 0.071 & 0.034 & 0.142 \\
\hline Rollinson et al. 2008 & 20 & 0.133 & 0.034 & 0.405 \\
\hline Paradisi et al. 2011 & 20 & 0.388 & 0.263 & 0.529 \\
\hline Anderson et al. 2008 & 20 & 0.131 & 0.087 & 0.193 \\
\hline Drvar et al. 2014 & 20 & 0.036 & 0.002 & 0.384 \\
\hline Feltkamp et al. 2003 & 20 & 0.067 & 0.047 & 0.095 \\
\hline Total for subgroup & & 0.125 & 0.068 & 0.218 \\
\hline Patel et al. 2008 & 24 & 0.092 & 0.048 & 0.167 \\
\hline Rollinson et al. 2008 & 24 & 0.133 & 0.034 & 0.405 \\
\hline Paradisi et al. 2011 & 24 & 0.327 & 0.211 & 0.468 \\
\hline Anderson et al. 2008 & 24 & 0.088 & 0.053 & 0.142 \\
\hline Feltkamp et al. 2003 & 24 & 0.111 & 0.085 & 0.144 \\
\hline Total for subgroup & & 0.134 & 0.072 & 0.235 \\
\hline Patel et al. 2008 & 36 & 0.184 & 0.119 & 0.273 \\
\hline Rollinson et al. 2008 & 36 & 0.067 & 0.009 & 0.352 \\
\hline Paradisi et al. 2011 & 36 & 0.367 & 0.245 & 0.509 \\
\hline Anderson et al. 2008 & 36 & 0.050 & 0.025 & 0.097 \\
\hline Total for subgroup & & 0.150 & 0.073 & 0.283 \\
\hline Rollinson et al. 2008 & 5 & 0.133 & 0.034 & 0.405 \\
\hline Faust et al. 2013 & 5 & 0.306 & 0.240 & 0.382 \\
\hline Paradisi et al.. 2011 & 5 & 0.327 & 0.211 & 0.468 \\
\hline Anderson et al. 2008 & 5 & 0.125 & 0.082 & 0.186 \\
\hline Feltkamp et al. 2003 & 5 & 0.007 & 0.002 & 0.021 \\
\hline Total for subgroup & & 0.136 & 0.072 & 0.241 \\
\hline Patel et al. 2008 & 8 & 0.041 & 0.015 & 0.104 \\
\hline Rollinson et al. 2008 & 8 & 0.267 & 0.104 & 0.533 \\
\hline Paradisi et al. 2011 & 8 & 0.245 & 0.145 & 0.383 \\
\hline Anderson et al. 2008 & 8 & 0.225 & 0.167 & 0.296 \\
\hline Drvar et al. 2014 & 8 & 0.036 & 0.002 & 0.384 \\
\hline Wielund et al. 2000 & 8 & 0.188 & 0.113 & 0.298 \\
\hline Feltkamp et al. 2003 & 8 & 0.032 & 0.019 & 0.054 \\
\hline Total for subgroup & & 0.125 & 0.071 & 0.209 \\
\hline Patel et al. 2008 & 93 & 0.184 & 0.119 & 0.273 \\
\hline Rollinson et al. 2008 & 93 & 0.067 & 0.009 & 0.352 \\
\hline Paradisi et al. 2011 & 93 & 0.429 & 0.299 & 0.569 \\
\hline Total for subgroup & & 0.238 & 0.108 & 0.448 \\
\hline Patel et al. 2008 & $\beta 1$ & 0.408 & 0.316 & 0.508 \\
\hline Zakrzewska et al. 2012 & $\beta 1$ & 0.480 & 0.384 & 0.577 \\
\hline Anderson et al. 2008 & $\beta 1$ & 0.291 & 0.272 & 0.312 \\
\hline Karags et al. 2010 & $\beta 1$ & 0.200 & 0.176 & 0.228 \\
\hline Total for subgroup & & 0.333 & 0.199 & 0.500 \\
\hline Overall & & 0.149 & 0.096 & 0.224 \\
\hline
\end{tabular}

Event rate and $95 \% \mathrm{CI}$

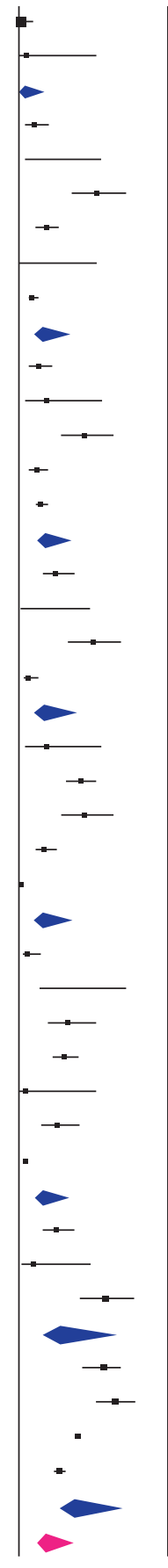

Fig. 5. The forest plot of event rate of (A) $\beta 1-\mathrm{HPV}$ and (B) $\beta 2-\mathrm{HPV}$ in BCC patients 
B

\begin{tabular}{|c|c|c|c|c|}
\hline \multirow[t]{2}{*}{ Study name } & \multirow[t]{2}{*}{ HPV type } & \multicolumn{3}{|c|}{ Statistics for each study } \\
\hline & & Event rate & Lowert limit & Upper limit \\
\hline Rollinson et al. 2008 & 107 & 0.067 & 0.009 & 0.352 \\
\hline Drvar et al. 2014 & 107 & 0.036 & 0.011 & 0.391 \\
\hline Total for subgroup & & 0.072 & 0.013 & 0.319 \\
\hline Patel et al. 2008 & 15 & 0.143 & 0.086 & 0.227 \\
\hline Rollinson et al. 2008 & 15 & 0.133 & 0.034 & 0.405 \\
\hline Paradisi et al. 2011 & 15 & 0.388 & 0.263 & 0.529 \\
\hline Anderson et al. 2008 & 15 & 0.100 & 0.062 & 0.157 \\
\hline Faust et al. 2013 & 15 & 0.181 & 0.129 & 0.249 \\
\hline Feltkamp et al. 2003 & 15 & 0.028 & 0.016 & 0.048 \\
\hline Total for subgroup & & 0.131 & 0.070 & 0.230 \\
\hline Patel et al. 2008 & 17 & 0.163 & 0.102 & 0.250 \\
\hline Rollinson et al. 2008 & 17 & 0.133 & 0.034 & 0.405 \\
\hline Paradisi et al. 2011 & 17 & 0.265 & 0.161 & 0.405 \\
\hline Total for subgroup & & 0.189 & 0.077 & 0.393 \\
\hline Patel et al. 2008 & 23 & 0.184 & 0.119 & 0.273 \\
\hline Rollinson et al. 2008 & 23 & 0.194 & 0.127 & 0.284 \\
\hline Paradisi et al. 2011 & 23 & 0.067 & 0.009 & 0.352 \\
\hline Total for subgroup & & 0.219 & 0.089 & 0.445 \\
\hline Patel et al. 2008 & 38 & 0.102 & 0.056 & 0.179 \\
\hline Rollinson et al. 2008 & 38 & 0.200 & 0.066 & 0.470 \\
\hline Paradisi et al. 2011 & 38 & 0.245 & 0.211 & 0.468 \\
\hline Anderson et al. 2008 & 38 & 0.156 & 0.082 & 0.186 \\
\hline Faust et al. 2013 & 38 & 0.263 & 0.200 & 0.336 \\
\hline Feltkamp et al. 2003 & 38 & 0.023 & 0.012 & 0.042 \\
\hline Forslund et al. 2003 & 38 & 0.160 & 0.061 & 0.357 \\
\hline Wieland et al. 2000 & 38 & 0.246 & 0.159 & 0.361 \\
\hline Total for subgroup & & 0.149 & 0.088 & 0.241 \\
\hline Patel et al. 2008 & 75 & 0.010 & 0.001 & 0.069 \\
\hline Rollinson et al. 2008 & 75 & 0.200 & 0.066 & 0.470 \\
\hline Paradisi et al. 2011 & 75 & 0.327 & 0.211 & 0.468 \\
\hline Total for subgroup & & 0.151 & 0.054 & 0.355 \\
\hline Patel et al. 2008 & 9 & 0.184 & 0.119 & 0.273 \\
\hline Rollinson et al. 2008 & 9 & 0.133 & 0.034 & 0.405 \\
\hline Paradisi et al. 2011 & 9 & 0.265 & 0.161 & 0.405 \\
\hline Andersson et al. 2008 & 9 & 0.217 & 0.130 & 0.338 \\
\hline Total for subgroup & & 0.203 & 0.097 & 0.378 \\
\hline Patel et al. 2008 & $\beta 2$ & 0.571 & 0.472 & 0.665 \\
\hline Anderson et al. 2008 & $\beta 2$ & 0.326 & 0.306 & 0.347 \\
\hline Total for subgroup & & 0.442 & 0.207 & 0.705 \\
\hline Overall & & 0.181 & 0.120 & 0.264 \\
\hline
\end{tabular}

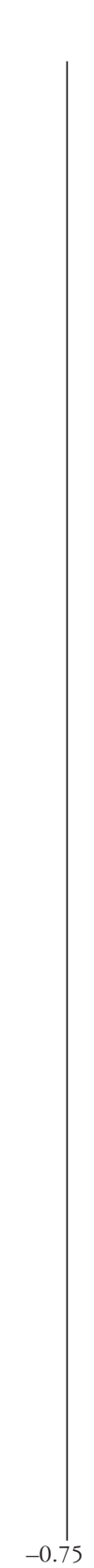

Event rate and $95 \% \mathrm{CI}$
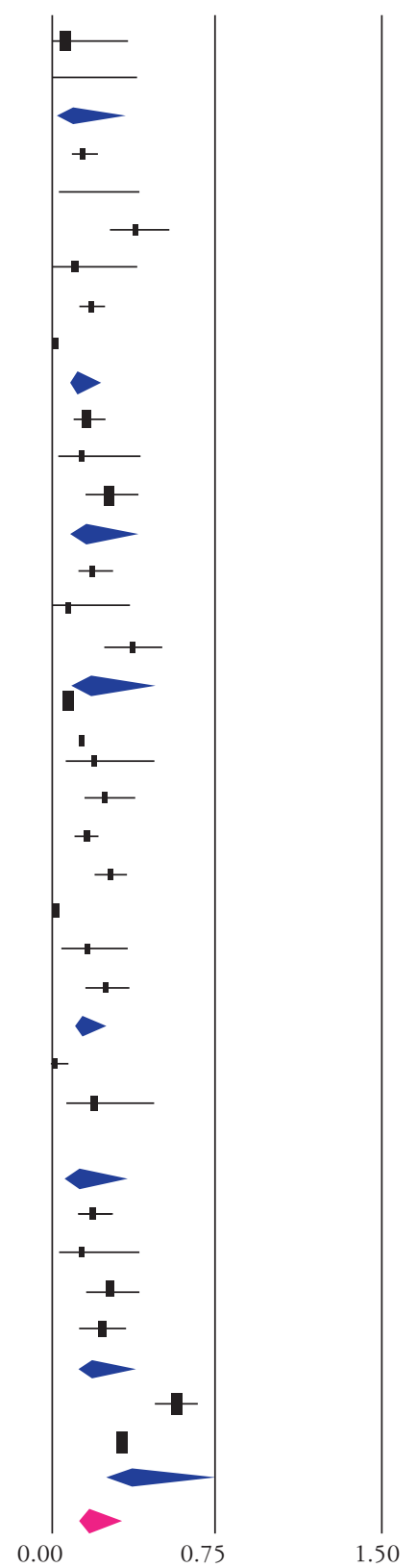

Fig. 5. Cont.

[32] that concluded that HPV was not likely to have a major role in the pathogenesis of BCC.

In one study [14], $\alpha-\mathrm{HPV}$ in BCC was positive in $35 \%$ of the cases that the high-risk HPV genotypes observed in these patients were HPV 16, 35, 58 and 59. The findings of a research [5] demonstrated that $\beta 1-H P V s$ were the most common HPV types detected in the skin of BCC patients. Moreover, these types and mixed infections are significantly more frequent in tumor samples than in healthy perilesional skin and the results suggested that the types as well as co-infection with more than one viral type could be important in BCC.
The findings suggested that EV-HPV types could be present in a higher percentage of skin cancers [25] and that EV-HPV-directed seroresponses were induced upon skin cancer formation, rather than upon infection [28].

Also, the findings of another study suggested that high-risk mucosal HPV types recently identified as significant risk factors for non-melanoma skin cancer [34] and also represents a risk factor for non-melanoma skin cancer in a non-immunosuppressed population [36]. Other results suggested that HPVs, particularly the oncogenic potential of certain types such as HPV 8, 18, and 5 could induce non-melanoma skin cancers [38]. 


\begin{tabular}{|c|c|c|c|c|}
\hline \multirow[t]{2}{*}{ STUdY NAME } & \multirow[t]{2}{*}{ HPV TYPE } & \multicolumn{3}{|c|}{ STATISTICS FOR EACH STUDY } \\
\hline & & EVENT RATE & LOWERT LIMIT & UPPER LIMIT \\
\hline Patel et al. 2008 & 49 & 0.005 & 0.000 & 0.076 \\
\hline Rollinson et al. 2008 & 49 & 0.200 & 0.066 & 0.470 \\
\hline Paradisi et al. 2011 & 49 & 0.245 & 0.145 & 0.383 \\
\hline Total for subgroup & & 0.179 & 0.090 & 0.327 \\
\hline Patel et al. 2008 & 76 & 0.255 & 0.179 & 0.350 \\
\hline Rollinson et al. 2008 & 76 & 0.031 & 0.002 & 0.350 \\
\hline Paradisi et al. 2011 & 76 & 0.224 & 0.129 & 0.362 \\
\hline Faust et al. 2013 & 76 & 0.256 & 0.195 & 0.329 \\
\hline Total for subgroup & & 0.234 & 0.154 & 0.338 \\
\hline Overall & & 0.217 & 0.152 & 0.299 \\
\hline
\end{tabular}

A

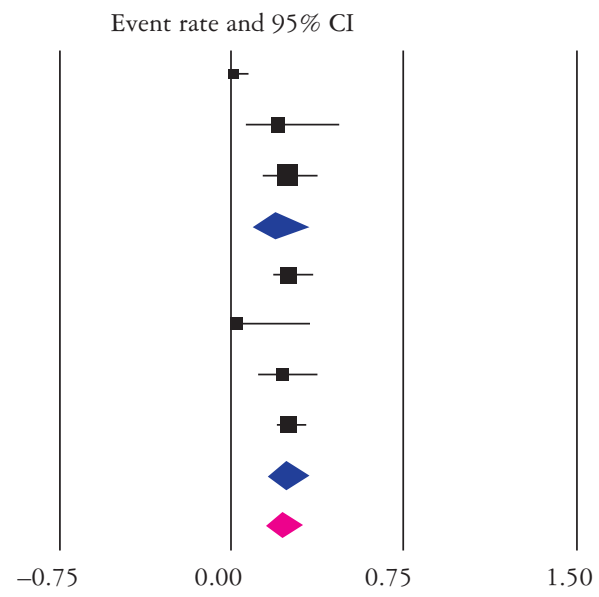

\begin{tabular}{|c|c|c|c|c|}
\hline \multirow[t]{2}{*}{ STUdY NAME } & \multirow{2}{*}{$\begin{array}{c}\text { SubGROUP } \\
\text { WITHIN } \\
\text { STUDY }\end{array}$} & \multicolumn{3}{|c|}{ STATISTICS FOR EACH STUDY } \\
\hline & & EVENT RATE & LOWERT LIMIT & UPPER LIMIT \\
\hline Patel et al. 2008 & 92 & 0.020 & 0.005 & 0.078 \\
\hline Rollinson et al. 2008 & 92 & 0.067 & 0.009 & 0.352 \\
\hline Total for subgroup & & 0.035 & 0.004 & 0.235 \\
\hline Patel et al. 2008 & 96 & 0.020 & 0.005 & 0.078 \\
\hline Rollinson et al. 2008 & 96 & 0.200 & 0.066 & 0.470 \\
\hline Total for subgroup & & 0.069 & 0.010 & 0.357 \\
\hline Overall & & 0.050 & 0.012 & 0.187 \\
\hline
\end{tabular}

\begin{tabular}{|c|c|c|c|}
\hline \multirow[t]{2}{*}{ StUdy NAME } & \multicolumn{3}{|c|}{ STATISTICS FOR EACH STUDY } \\
\hline & EVENT RATE & LOWERT LIMIT & UPPER LIMIT \\
\hline Berberta et al. 2004 & 0.609 & 0.402 & 0.782 \\
\hline Berant-Garcia et al. 2014 & 0.577 & 0.385 & 0.748 \\
\hline Posteraro et al.1996 & 0.019 & 0.001 & 0.244 \\
\hline Shamanin et al. 1996 & 0.438 & 0.225 & 0.676 \\
\hline Trenfield et al. 2008 & 0.091 & 0.013 & 0.439 \\
\hline Mokhtari et al. 2009 & 0.100 & 0.051 & 0.187 \\
\hline Total & 0.264 & 0.098 & 0.544 \\
\hline
\end{tabular}
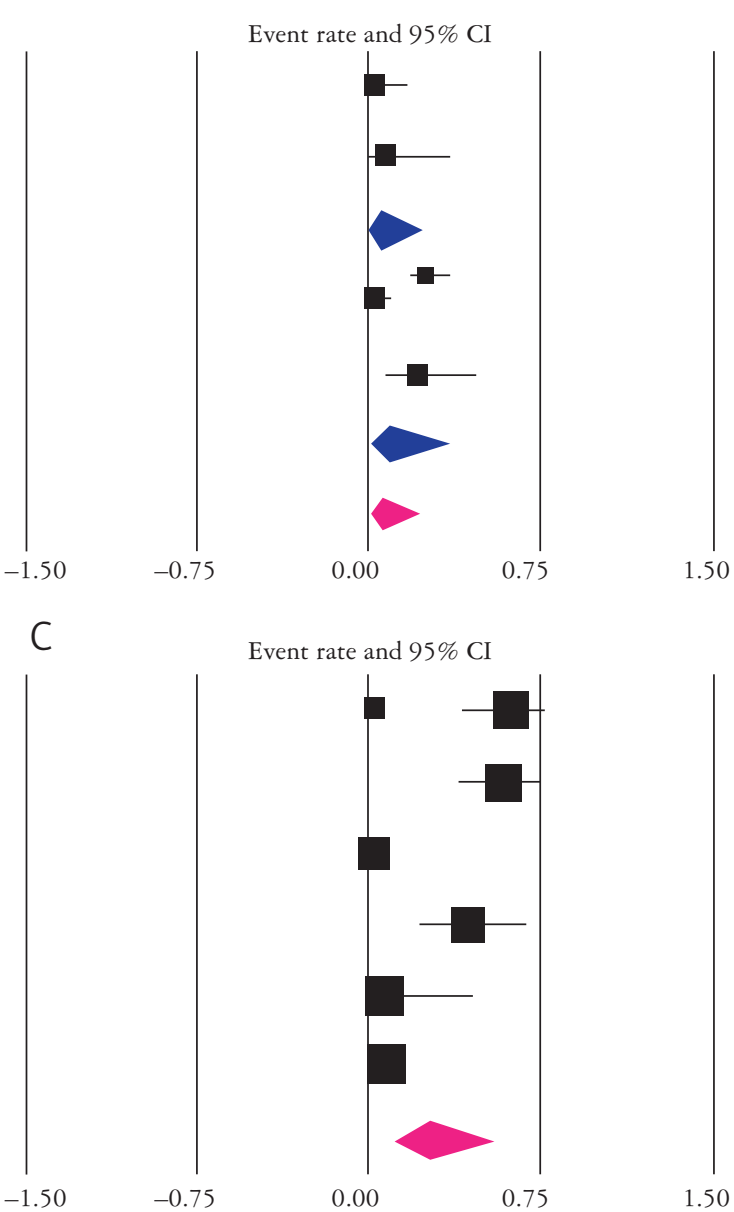

Fig. 6. The forest plot of event rate of (A) $\beta 3-\mathrm{HPV}$, (B) $\beta 4$ - and $\beta 5$-HPVs and (C) HPV (unlisted) in BCC patients

\section{Conclusions}

Limitations such as the variation of HPVs, reporting HPVs in serum instead of tissue in some studies, and few studies reported; were caused that the relationship between HPV types and BCC have been not well done in the meta-analysis. Although there were a few case-control studies about the risk of HPVs in the BCC group compared with the healthy control, but this meta-analysis showed that probably the risk of $\gamma$-HPV was more in BCC patients. Also, the rate of $\gamma$-HPV was higher than $\alpha-, \beta$ - and EV-HPVs in the BCC patients.

The authors declare no conflict of interest. 


\section{References}

1. Correa RM, Vladimirsky S, Heideman DA, et al. Cutaneous human papillomavirus genotypes in different kinds of skin lesions in Argentina. J Med Virol 2017; 89: 352-357.

2. Drvar DL, Lipozencić J, Sabol I, et al. Human papillomavirus status in extragenital nonmelanoma skin cancers. Clin Dermatol 2014; 32: 248-252.

3. Forman D, de Martel C, Lacey CJ, et al. Global burden of human papillomavirus and related diseases. Vaccine 2012; 30: F12-23.

4. Bernard HU, Burk RD, Chen Z, et al. Classification of papillomaviruses (PVs) based on 189 PV types and proposal of taxonomic amendments. Virology 2010; 401: 70-79.

5. Zakrzewska K, Regalbuto E, Pierucci F, et al. Pattern of HPV infection in basal cell carcinoma and in perilesional skin biopsies from immunocompetent patients. Virol J 2012; 9: 309.

6. Goodwin EC, DiMaio D. Repression of human papillomavirus oncogenes in HeLa cervical carcinoma cells causes the orderly reactivation of dormant tumor suppressor pathways. Proc Natl Acad Sci USA 2000; 97: 12513-12518.

7. Kreuter A, Hochdorfer B, Brockmeyer NH, et al. A human papillomavirus-associated disease with disseminated warts, depressed cell-mediated immunity, primary lymphedema, and anogenital dysplasia: WILD syndrome. Arch Dermatol 2008; 144: 366-372.

8. Bernat-García J, Morales Suárez-Varela M, Vilata-Corell JJ, et al. Detection of human papillomavirus in nonmelanoma skin cancer lesions and healthy perilesional skin in kidney transplant recipients and immunocompetent patients. Actas Dermosifiliogr 2014; 105: 286-294.

9. Mokhtari M, Mesbah A, Rajabi P, et al. Determination of the relationship between Basal cell carcinoma and human papilloma virus, based on immunohistochemistry staining method. Indian J Dermatol 2009; 54: 225-228.

10. Roewert-Huber J, Lange-Asschenfeldt B, Stockfleth E, et al. Epidemiology and etiology of basal cell carcinoma. Br J Dermatol 2007; 157: 47-51.

11. Escutia B, Ledesma E, Serra-Guillen C, et al. Detection of human papilloma virus in normal skin and in superficial and nodular basal cell carcinomas in immunocompetent subjects. J Eur Acad Dermatol Venereol 2011; 25: 832-838.

12. Forslund O, Ly H, Reid C, et al. A broad spectrum of human papillomavirus types is present in the skin of Australian patients with non-melanoma skin cancers and solar keratosis. $\mathrm{Br}$ J Dermatol 2003; 149: 64-73.

13. Trenfield K, Salmond CA, Pope JH, et al. Southern blot analysis of skin biopsies for human papillomavirus DNA: renal allograft recipients in south-eastern Queensland. Australas J Dermatol 1993; 34: 71-78.

14. Rotaru M, Iancu G, Mihalache M, et al. $\alpha-H P V$ positivity analysis in a group of patients with melanoma and non-melanoma skin cancers. Rom J Lab Med 2014; 22: 471-478.

15. Elwood H, Kim J, Yemelyanova A, et al. Basal cell carcinomas of the vulva: high-risk human papillomavirus DNA detection, p16 and BerEP4 expression. Am J Surg Pathol 2014; 38: 542 547.

16. Iannacone MR, Gheit T, Waterboer T, et al. Case-control study of cutaneous human papillomavirus infection in Basal cell carcinoma of the skin. J Invest Dermatol 2013; 133: 1512-1520.

17. Karagas MR, Nelson $\mathrm{HH}$, Sehr P, et al. Human papillomavirus infection and incidence of squamous cell and basal cell carcinomas of the skin. J Natl Cancer Inst 2006; 98: 389-395.

18. Gibson GE, Ahmed I. Perianal and genital basal cell carcinoma: A clinicopathologic review of 51 cases. J Am Acad Dermatol 2001; 45: 68-71

19. Pierceall WE, Goldberg LH, Ananthaswamy HN. Presence of human papilloma virus type 16 DNA sequences in human nonmelanoma skin cancers. J Invest Dermatol 1991; 97: 880884 .

20. Karagas MR, Spencer SK, Weinstock MA, et al. Rarity of Human Papillomavirus in Nonmelanoma Skin Cancer among Immunocompetent Patients. J Cutan Med Surg 1997; 2: 16-19.

21. Patel AS, Karagas MR, Perry AE, et al. Exposure profiles and human papillomavirus infection in skin cancer: an analysis of 25 genus beta-types in a population-based study. J Invest Dermatol 2008; 128: 2888-2893.

22. Karagas MR, Waterboer T, Li Z, et al. Genus beta human papillomaviruses and incidence of basal cell and squamous cell carcinomas of skin: population based case-control study. BMJ 2010; 341: c2986

23. Rollison DE, Pawlita M, Giuliano AR, et al. Measures of cutaneous human papillomavirus infection in normal tissues as biomarkers of HPV in corresponding nonmelanoma skin cancers. Int J Cancer 2008; 123: 2337-2342.

24. Iannacone MR, Wang W, Stockwell HG, et al. Sunlight exposure and cutaneous human papillomavirus seroreactivity in basal cell and squamous cell carcinomas of the skin. J Infect Dis 2012; 206: 399-406.

25. Tieben LM, Berkhout RJ, Smits HL, et al. Detection of epidermodysplasia verruciformis-like human papillomavirus types in malignant and premalignant skin lesions of renal transplant recipients. Br J Dermatol 1994; 131: 226-230.

26. de Jong-Tieben LM, Berkhout RJ, Smits HL, et al. High frequency of detection of epidermodysplasia verruciformis-associated human papillomavirus DNA in biopsies from malignant and premalignant skin lesions from renal transplant recipients. J Invest Dermatol 1995; 105: 367-371.

27. Berkhout RJ, Bouwes Bavinck JN, ter Schegget J. Persistence of human papillomavirus DNA in benign and (pre)malignant skin lesions from renal transplant recipients. J Clin Microbiol 2000; 38: 2087-2096.

28. Feltkamp MC, Broer R, di Summa FM, et al. Seroreactivity to epidermodysplasia verruciformis-related human papillomavirus types is associated with nonmelanoma skin cancer. Cancer Res 2003; 63: 2695-2700.

29. Berberta ALCV, Manteseb SADO, Filhoc LRG, et al. Detection of Human Papillomavirus in Basal Cell Carcinoma by Polymerase Chain Reaction. Med Cutan Iber Lat Am 2004; 32 : 205-209.

30. Yang JF, Zhao CZ, Lu KX. Development and application of a rapid detection system for human papillomavirus and Herpes simplex virus-2 by loop-mediated isothermal amplification assay. Microb Pathog 2016; 97: 178-182.

31. Harwood CA, Surentheran T, McGregor JM, et al. Human papillomavirus infection and non-melanoma skin cancer in immunosuppressed and immunocompetent individuals. J Med Virol 2000; 61: 289-297.

32. Nahidi Y, Meibodi NT, Meshkat Z, et al. No Evidence of Human Papilloma Virus Infection in Basal Cell Carcinoma. Indian J Dermatol 2015; 60: 356-359.

33. Ramezani M, Abdali E, Khazaei S, et al. P16INK4a Immunostaining but Lack of Human Papilloma Virus Type 16 in Cutaneous Squamous Cell Carcinoma and Basal Cell Carcinoma: a Report from West Iran. Asian Pac J Cancer Prev 2016; 17: 1093-1096.

34. Shahmahmoudi S, Mahmoodi M, Azad TM, et al. Prevalence of mucosal types of human papillomavirus in skin lesions in north part of Iran. Cancer Lett 2007; 247: 72-76.

35. Luron L, Avril MF, Sarasin A, et al. Prevalence of human papillomavirus in skin tumors from repair deficient xeroderma pigmentosum patients. Cancer Lett 2007; 250: 213-219.

36. Iftner A, Klug SJ, Garbe C, et al. The prevalence of human papillomavirus genotypes in nonmelanoma skin cancers of nonimmunosuppressed individuals identifies high-risk geni- 
tal types as possible risk factors. Cancer Res 2003; 63: 7515 7519.

37. Zaravinos A, Kanellou P, Spandidos DA. Viral DNA detection and RAS mutations in actinic keratosis and nonmelanoma skin cancers. Br J Dermatol 2010; 162: 325-331.

38. Biliris KA, Koumantakis E, Dokianakis DN, et al. Human papillomavirus infection of non-melanoma skin cancers in immunocompetent hosts. Cancer Lett 2000; 161: 83-88.

39. Forslund O, Lindelöf B, Hradil E, et al. High prevalence of cutaneous human papillomavirus DNA on the top of skin tumors but not in "Stripped" biopsies from the same tumors. J Invest Dermatol 2004; 123: 388-394.

40. Reuschenbach M, Tran T, Faulstich F, et al. High-risk human papillomavirus in non-melanoma skin lesions from renal allograft recipients and immunocompetent patients. $\mathrm{Br} \mathrm{J}$ Cancer 2011; 104: 1334-1341.

41. Stockfleth E, Nindl I, Sterry W, et al. Human papillomaviruses in transplant-associated skin cancers. Dermatol Surg 2004; 30: 604-609.

42. Posteraro P, Didona B, Papi M, et al. Analisi del DNA di papillomavirus umani (HPV) mediante reazione polimerasica a catena (PCR) in lesioni cutanee tumorali. Dermatologia Clinica 1996; 16 (1).

43. Paolini F, Carbone A, Benevolo M, et al. Human Papillomaviruses, p16INK4a and Akt expression in basal cell carcinoma. J Exp Clin Cancer Res 2011; 30: 108.

44. Borgogna C, Lanfredini S, Peretti A, et al. Improved detection reveals active $\beta$-papillomavirus infection in skin lesions from kidney transplant recipients. Mod Pathol 2014; 27: 11011115 .

45. Paradisi A, Waterboer T, Sampogna F, et al. Seropositivity for human papillomavirus and incidence of subsequent squamous cell and basal cell carcinomas of the skin in patients with a previous nonmelanoma skin cancer. Br J Dermatol 2011; 165: 782-791.

46. Shamanin V, zur Hausen H, Lavergne D, et al. Human papillomavirus infections in nonmelanoma skin cancers from renal transplant recipients and nonimmunosuppressed patients. J Natl Cancer Inst 1996; 88: 802-811.

47. Wieland U, Stoltidis M, Weissenborn S, et al. Papillomavirus DNA in Basal Cell Carcinomas of Immunocompetent Patients: an Accidental Association? J Invest Dermatol 2000; 115: 124-128.

48. Andersson K, Michael KM, Luostarinen T, et al. Prospective study of human papillomavirus seropositivity and risk of nonmelanoma skin cancer. Am J Epidemiol 2012; 175: 685-695.

49. Faust H, Andersson K, Forslund O, et al. Pseudovirion-binding and neutralizing antibodies to cutaneous Human Papillomaviruses correlated to presence of HPV DNA in skin. J Gen Virol 2013; 94: 1096-1103.

50. Andersson K, Waterboer T, Kirnbauer R, et al. Seroreactivity to cutaneous human papillomaviruses among patients with nonmelanoma skin cancer or benign skin lesions. Cancer Epidemiol Biomarkers Prev 2008; 17: 189-195.

51. Sobjanek M, Bien E, Zablotna M, et al. Soluble interleukin-2 receptor $\alpha$ and interleukin-2 serum levels in patients with basal cell carcinoma. Postepy Dermatol Alergol 2016; 33: 263-268.

52. Sobjanek M, Zabłotna M, Szczerkowska-Dobosz A, et al. -2518 A/G MCP-1 but not -403 G/A RANTES gene polymorphism is associated with enhanced risk of basal cell carcinoma. Postepy Dermatol Alergol 2016; 33: 381-385.

\section{Address for correspondence}

Masoud Sadeghi

Medical Biology Research Center

Kermanshah University of Medical Sciences

Kermanshah, Iran

e-mail: sadeghi_mbrc@yahoo.com 